Original Article

\title{
Antinociceptive and anti-inflammatory activities of Hymenaea martiana Hayne (Fabaceae) in mice
}

\author{
Atividade antinociceptiva e anti-inflamatória de Hymenaea martiana Hayne (Fabaceae) \\ em camundongos
}

\author{
A. G. M. Pacheco (D), E. J. Pachecob (D), L. A. R. O. Macedoc (D), J. C. Silvac (D), S. R. G. Lima-Saraivac (D), V. P. Barros` (D),

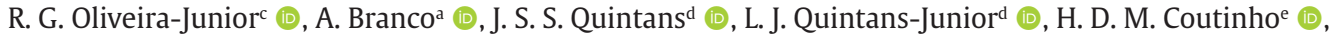 \\ I. R. A. Menezes ${ }^{e}$ (D) and J. R. G. S. Almeidaa,c* (D) \\ a Universidade Estadual de Feira de Santana - UEFS, Programa de Pós-Graduação em Biotecnologia, Feira de Santana, BA, Brasil \\ 'Universidade de Pernambuco - UPE, Pós-Graduação em Perícia Forense, Camaragibe, PE, Brasil \\ c Universidade Federal do Vale do São Francisco - UNIVASF, Núcleo de Estudos e Pesquisas de Plantas Medicinais - NEPLAME, Petrolina, PE, Brasil \\ ${ }^{\mathrm{d} U n i v e r s i d a d e ~ F e d e r a l ~ d e ~ S e r g i p e ~-~ U F S, ~ D e p a r t m e n t o ~ d e ~ F i s i o l o g i a, ~ A r a c a j u, ~ S E, ~ B r a s i l ~}$ \\ e Universidade Regional do Cariri - URCA, Departmento de Química Biológica, Crato, CE, Brasil
}

\begin{abstract}
Hymenaea martiana is a species popularly known in Northeastern Brazil as "jatobá" and used in folk medicine to treat pain and inflammation. The aim of this work was to evaluate the antinociceptive and anti-inflammatory activity of $\mathrm{H}$. martiana. In the present study, we carried out an investigation about the effects of the crude ethanolic extract $(\mathrm{Hm}-\mathrm{EtOH})$ and the ethyl acetate fraction (Hm-AcOEt) in models of nociception and inflammation in mice. Chemical (acetic acid-induced writhing and formalin) and thermal stimuli (hot plate) were used for the evaluation of antinociceptive activity, while for the anti-inflammatory profile paw edema induced by carrageenan was used, along with leukocyte migration to the peritoneal cavity. The presence of the flavonoid astilbin in the samples was characterized through HPLC-DAD-MS analysis. Hm-EtOH and Hm-AcOEt (100, 200 and 400 mg.kg-1 ${ }^{-1}$, i.p.) significantly reduced the number of abdominal contortions and decreased the paw licking time in the formalin test. In the hot plate, the extract increased the latency time of animals. $\mathrm{Hm}$-EtOH and $\mathrm{Hm}$-AcOEt inhibited significantly the increase in the edema after the administration of carrageenan. $\mathrm{Hm}-\mathrm{EtOH}$ and $\mathrm{Hm}$-AcOEt inhibited leukocyte migration in the peritonitis test. HPLC-DAD-MS analysis of Hm-EtOH and Hm-AcOEt revealed the presence of the flavonoid astilbin in the samples. According to the results of this study, both $\mathrm{Hm}$-EtOH and Hm-AcOEt have antinociceptive and anti-inflammatory activities, which could be related with the presence of flavonoid in the extracts. The results reinforce the popular use of this plant.
\end{abstract}

Keywords: pain, inflammation, medicinal plants, Caatinga.

\begin{abstract}
Resumo
Hymenaea martiana é uma espécie popularmente conhecida no Nordeste do Brasil como "jatobá" e usada na medicina popular para tratar a dor e a inflamação. $\mathrm{O}$ objetivo deste trabalho foi avaliar a atividade antinociceptiva e antiinflamatória de H. martiana. No presente estudo, foram avaliados os efeitos do extrato etanólico bruto (Hm-EtOH) e da fração acetato de etila (Hm-AcOEt) em modelos de nocicepção e inflamação em camundongos. Foram utilizados estímulos químicos (contorções abdominais induzidas por ácido acético e teste da formalina) e estímulo térmico (teste da placa quente) para avaliação da atividade antinociceptiva, enquanto no perfil anti-inflamatório foi utilizado o teste do edema de pata induzido por carragenina e migração de leucócitos para a cavidade peritoneal. A presença do flavonoide astilbina nas amostras foi caracterizada através de análise por CLAE-DAD-EM. Hm-EtOH e o Hm-AcOEt $(100,200$ e 400 mg.kg-1 , i.p.) reduziram significativamente o número de contorções abdominais e diminuíram o tempo de lambida da pata no teste da formalina. No teste da placa quente, houve aumento do tempo de latência dos animais. Hm-EtOH e Hm-AcOEt inibiram significativamente o aumento do edema após a administração de carragenina, bem como inibiram a migração de leucócitos no teste de peritonite. A análise por CLAE-DAD-EM de $\mathrm{Hm}-\mathrm{EtOH}$ e Hm-AcOEt revelou a presença do flavonoide astilbina nas amostras. De acordo com os resultados deste estudo, tanto $\mathrm{Hm}$-EtOH quanto o Hm-AcOEt possuem atividades antinociceptiva e anti-inflamatória, o que pode estar relacionado à presença do flavonoide. Os resultados reforçam o uso popular desta planta.
\end{abstract}

Palavras-chave: dor, inflamação, plantas medicinais, Caatinga.

*e-mail: jackson.guedes@univasf.edu.br

Received: July 1, 2020 - Accepted: November 13, 2020

This is an Open Access article distributed under the terms of the Creative Commons Attribution License, which permits unrestricted use, distribution, and reproduction in any medium, provided the original work is properly cited. 


\section{Introduction}

The large plant biodiversity in Brazil favors the discovery of new bioactive compounds. There are five regions in abundance of medicinal species: Amazon Forest, Atlantic Forest, Pantanal of Mato Grosso, Cerrado and Caatinga. Some of these regions have medicinal plants commonly used, which have not yet received chemical, pharmacological or toxicological studies (Souza et al., 2014; Almeida et al., 2010).

The Caatinga forest consists of a flora rich in endemic taxons (Mertens et al., 2017; Ribeiro et al., 2014; Giulietti et al., 2005) that comprises a kind of vegetation that is exclusive to Brazil and that covers most of the region with semi-arid climate, which is characterized by having high temperatures, low relative air humidity and low rainfall volumes. These adverse circumstances require a necessary adaptation of plants to the region, favoring the synthesis of a wide variety of adaptive molecules. The Caatinga biome offers a wide variety of animals and plants that are used for food, fuel, building materials and medicinal purposes (Lemos et al., 2016). These factors associated with the traditional knowledge suggests that plant species belonging to the Fabaceae family, the more diverse of the Caatinga (Giordani et al., 2008), emerge as a promising source of new bioactive substances.

Species of the Fabaceae family can be found in different regions of the world and are divided into three subfamilies: Mimosoideae, Papilionoideae and Caesalpinioideae. In the Caesalpinioideae subfamily is the genus Hymenaea found (Dutra et al., 2008). Species of this genus have economic value by providing wood, resins, fruits and edible barks, which are commonly used in Brazilian traditional medicine for different medicinal purposes (Gazzaneo et al., 2005). Hymenaea species are known to contain mainly diterpenoid compounds in extracts of trunk resin and barks (Agra et al., 2007). Diterpenes of the enantio-labdanoic type in the trunk resin and bark extract and ent-halimane in the seed pod resin, as well as clerodane-type diterpenes, were isolated from species of this genus (Doménech-Carbó et al., 2009; Cunningham et al., 1974; Khoo et al., 1973). Following our studies of the medicinal plants from the Caatinga biome, we have undertaken a study with $H$. martiana, a tree popularly known as "jatobá", which is used in folk medicine to treat pain and inflammation. Previous studies have showed biological activities related with the hydroalcoholic extract obtained from the barks (Neves et al., 1993).

In the present work, the antinociceptive and antiinflammatory effects of this species were evaluated through the ethanolic extract and ethyl acetate fraction of the stem bark in experimental protocols in mice. This study could be relevant for the understanding of the pharmacological potentialities of the Brazilian flora, particularly species native to the Caatinga biome.

\section{Material and Methods}

\subsection{Ethical aspects and botanical material}

This research was approved by the Ethics Committee and Studies with Humans and Animals (CEEHA). It was also approved by the Federal University of San Francisco Valley Animal Care and Use Committee under the number 024240408. The trunk barks of $H$. martiana were collected in Petrolina, Pernambuco, Brazil, in January 2011, and identified by André P. Fontana, a botanist from Centro de Referência para Recuperação de Áreas Degradadas (CRAD). The voucher specimen (6444) is deposited at the Herbarium of Vale do São Francisco (HVASF). All procedures for the access to genetic patrimony and to associated traditional knowledge were carried out and the project was registered in SisGen (Register \#A3E4538).

\subsection{Extraction}

The trunk barks of $H$. martiana were dried and extracted with ethanol(EtOH) 95\% at room temperature during $72 \mathrm{~h}$ according to Silva et al. (2012). The EtOH solution was concentrated under vacuum yielding with $90 \mathrm{~g}$ of crude ethanolic extract of $\mathrm{H}$. martiana (Hm-EtOH). The Hm-EtOH was suspended in a mixture of methanol $(\mathrm{MeOH})$ and water $\left(\mathrm{H}_{2} \mathrm{O}\right)$ (proportion 3:7 v/v) and partitioned with hexane, chloroform $\left(\mathrm{CHCl}_{3}\right)$ and ethyl acetate (AcOEt) in ascending order of polarity to yield the respective fractions. The AcOEt solution was concentrated under vacuum yielding with $18.02 \mathrm{~g}$, and thus was the ethyl acetate fraction of $H$. martiana (Hm-AcOEt) obtained.

\subsection{HPLC-DAD-MS analysis of phenolic compounds in the extract and fraction of $\mathrm{H}$. martiana}

A Shimadzu Prominence ${ }^{\circledR}$ HPLC system was used for the HPLC-DAD analyses. The system was equipped with two binary pumps (LC-20AD), degassing unit (DGU-20A), auto sampler (SIL-20AHT), column oven (CTO-20A), communication bus module (CBM-20A), diode array detector (SPD-M20A) and a reverse phase column (Luna Phenomenex, $250 \mathrm{~mm}$ x $4.6 \mathrm{~mm}, 5 \mu \mathrm{m}$ ), following the method described by Silva et al. (2012). For analysis of LC-MS, a HPLC system was coupled to an AmaZon SL ion trap mass spectrometer (Bruker Daltonics ${ }^{\circledR}$ ) equipped with electrospray ion source and ion trap analyzer, under the following conditions: capillary: $3500 \mathrm{~V}$; end plate offset $500 \mathrm{~V}$; nebulizer 50 psi; dry gas flow: $9.0 \mathrm{~L}^{\mathrm{min}}{ }^{-1}$ and dry gas temperature: $300{ }^{\circ} \mathrm{C}$.

Astilbin was identified in the crude ethanolic extract and ethyl acetate fraction by comparing the identified compound with commercial standard using the retention time, the absorbance spectrum profile and also the mass spectra obtained in positive and negative modes.

\subsection{Animals}

All experiments were conducted using 8-week-old male Swiss mice (Mus musculus) ( $25 \pm 5 \mathrm{~g}$ ). The animals were kept in groups of six animals $(n=6)$, which were housed in cages at $22 \pm 2{ }^{\circ} \mathrm{C}$ on a $12 \mathrm{~h} \mathrm{light/dark} \mathrm{cycle} \mathrm{(lights} \mathrm{on}$ at 6:00) with free access to food and water.

\subsection{Acetic acid-induced nociception}

This test was performed using the method described by Collier et al. (1968) with slight modifications. All administrations were via intraperitoneal (i.p.) route. 
Nociception was induced by acetic acid $(0.9 \% \mathrm{v} / \mathrm{v})$ in a volume of $0.1 \mathrm{~mL} \cdot 10 \mathrm{~g}^{-1}$. Animals were treated with saline (i.p.), Hm-EtOH or Hm-AcOEt (100, 200 and 400 mg.kg-1, i.p.) $30 \mathrm{~min}$ before the nociceptive agent. Indomethacin (20 mg.kg-1) and morphine (10 mg.kg-1) were used as positive control and injected $30 \mathrm{~min}$ before nociceptive agent. After the injection of acetic acid, the number of abdominal constrictions (contraction of the abdominal wall, pelvic rotation followed by hind limb extension) occurring between 5 and 15 min after injection was registered.

\subsection{Formalin-induced nociception}

Aformalinsolution(2.5\% in $0.9 \%$ sterilesaline, $20 \mu \mathrm{L} /$ animal) was injected into the right hind paw of the mice (Hunskaar and Hole, 1987). Mice were observed and the amount of time (in seconds) spent licking and biting the injected paw was measured as an indicator of pain. Responses were measured for 5 min after formalin injection (first phase, neurogenic) and 15-30 min after formalin injection (second phase, inflammatory) (Tjølsen et al., 1992). Treatments with saline (i.p.), Hm-EtOH and Hm-AcOEt (100, 200 and $400 \mathrm{mg} . \mathrm{kg}^{-1}$, i.p.), indomethacin ( $20 \mathrm{mg} \cdot \mathrm{kg}^{-1}$, i.p.) and morphine $\left(10 \mathrm{mg} . \mathrm{kg}^{-1}\right.$, i.p.) were administered $60 \mathrm{~min}$ before the injection of formalin. Antinociceptive activity was calculated as the percentage inhibition of licking time.

\subsection{Hot-plate test}

$24 \mathrm{~h}$ before the experiments, the animals were preselected and then those animals that presented latency time higher than 20 s were excluded from this study. Mice were subjected to the hot-plate apparatus (Insight, Brazil) at the temperature of the hot plate regulated to $55 \pm 1{ }^{\circ} \mathrm{C}$. Mice were pre-treated with saline (i.p.), $\mathrm{Hm}$-EtOH or Hm-AcOEt (100, 200 and 400 mg.kg-1 , i.p.), or morphine (10 mg.kg-1, i.p.). Each animal was placed on the heated surface of the plate and the latency to a discomfort reaction (licking of the paws or jumping) was recorded at 30,60, 90 and 120 min after the administration of the saline, extracts or morphine (Jacob and Ramabadran, 1978). The latencies for paw licking or jumping were recorded for each animal. Antinociceptive activity was calculated as the inhibition percentage of latency time.

\subsection{Carrageenan-induced hind paw edema}

The anti-inflammatory effect was evaluated according to the method described by Morris (2003). Paw edema was induced by carrageenan $2 \%$, injected at volume of $20 \mu \mathrm{L}$ into the subplantar region of the right hind paw of the mice. The basal (VA) volume of the right hind paw up to the ankle joint was measured using a plethysmometer (PanLab LE 7500, Spain). Immediately after that, the animals were pre-treated with $\mathrm{Hm}$-EtOH or Hm-AcOEt (100, 200 and $400 \mathrm{mg} . \mathrm{kg}^{-1}$, i.p.), saline (i.p.) or indomethacin (20 mg.kg-1 i.p.) and 1, 2, 3, 4 and 5 h after the intraplantar administration of carrageenan or saline injection, the mice pedal volume was measured (VB) as described previously (Huang et al., 2012). Inhibition of the paw edema was calculated by (VB-VA)/VA, where VA is the volume of the right hind paw before carrageenan injection and VB is the volume of the right hind paw after carrageenan injection.

\subsection{Leukocyte migration to the peritoneal cavity}

The leukocyte migration was induced by the injection of carrageenan (1\%, i.p., $0.25 \mathrm{~mL}$ ) into the peritoneal cavity of mice $1 \mathrm{~h}$ after the administration of $\mathrm{Hm}$-EtOH or Hm$\operatorname{AcOEt}\left(100,200\right.$ and 400 mg.kg-1 ${ }^{-1}$ i.p.) or with saline (i.p.) $0.5 \mathrm{~h}$ after the injection of dexamethasone ( $2 \mathrm{mg} . \mathrm{kg}^{-1}$, i.p. $)$ (Andrade et al., 2012; Bastos et al., 2007). The leukocyte migration was evaluated $4 \mathrm{~h}$ after the stimulus, when the animals were euthanized by means of cervical dislocation and the peritoneal cavity cells were harvested with saline (3 mL) containing EDTA ( $1 \mathrm{mM}$ ). Soon after that, a short and brief massage was made for further fluid collection, which was centrifuged (3,000 rpm for $6 \mathrm{~min})$ at room temperature. The supernatant was disposed and $1 \mathrm{~mL}$ of saline was added to the precipitate. An aliquot of $10 \mu \mathrm{L}$ from this suspension was dissolved in $200 \mu \mathrm{L}$ of Turk solution and the total cells were counted in a Neubauer chamber, under optic microscopy. The group treated with saline was considered as maximum of inflammation and all other treatments were compared to this group. The results were expressed as the number of leukocytes. $\mathrm{mL}^{-1}$ (Melo et al., 2011).

\subsection{Statistical analysis}

The results were presented as the mean \pm standard error of the mean (SEM) and the statistical significance was determined using an analysis of variance one way (ANOVA) followed by Tukey's test. In paw edema and hot plate experiments the statistical significance was determined using an analysis of variance two way (ANOVA) followed by Bonferroni's multiple comparisons test. Values were considered significantly different at $\mathrm{P}<0.05$. All analyses were performed using by Graph Pad Prism 6.0 software (GraphPad Prism Software Inc., San Diego, CA, USA).

\section{Results}

Both the preliminary analysis with HPLC-DAD and the analysis with LC-MS carried out by our research group demonstrated that the crude ethanolic extract and the ethyl acetate fraction from the barks of $H$. martiana contain the flavonoid astilbin. The flavonoid astilbin has retention time of $26.2 \mathrm{~min}$ and $\lambda_{\text {máx }} .290 \mathrm{~nm}$ (data not shown). The MS spectrum of astilbin showed $[\mathrm{M}+\mathrm{H}]^{+}$ion at $\mathrm{m} / \mathrm{z} 451$ and [M-H] - ion at $m / z 449$ in positive and negative modes, respectively (Figure $1 \mathrm{~A}$ and Figure $1 \mathrm{~B}$ ).

The results shown in Figures 2 and 3 demonstrated that Hm-EtOH and Hm-AcOEt (100, 200 and 400 mg.kg-1, i.p.) were capable of inhibiting $(\mathrm{P}<0.01)$ the abdominal writhing induced by the administration of acetic acid, when compared with the control group. The inhibitions of writhes by the administration of $\mathrm{Hm}-\mathrm{EtOH}$ were 36, 93 and $96 \%$, respectively. When Hm-AcOEt was administered, the inhibitions of writhes were 96, 97 and 97\%, respectively. Indomethacin and morphine produced 93 and 100\%, respectively, of reduction in acetic acid-induced writhing when compared with the control group.

Hm-EtOH at doses of 100, 200 and 400 mg.kg-1 (i.p.) produced a significant antinociceptive activity $(\mathrm{P}<0.05)$ in 

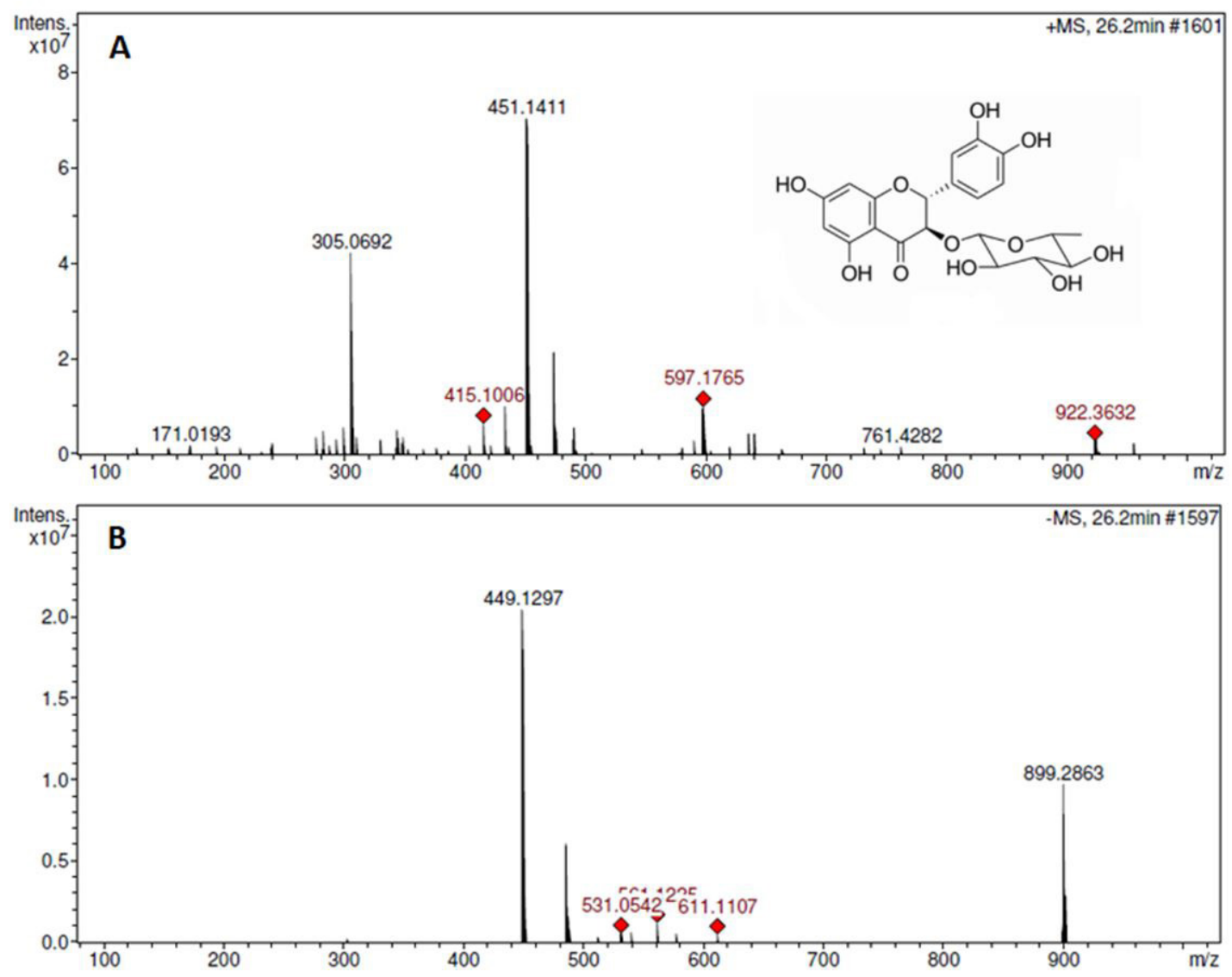

Figure 1. Mass spectrum of astilbin in ESI positive ( ${ }^{+} \mathrm{MS}$ ) and negative (-MS) modes. (A) LC-MS mass spectrum of astilbin in ESI positive molecular ion ( $\left.{ }^{+} \mathrm{MS}\right)$; (B) LC-MS mass spectrum of astilbin in ESI negative (-MS) molecular ions.

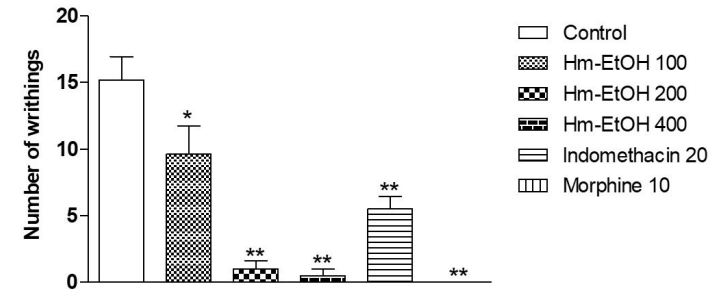

Figure 2. Effect of the ethanolic extract of Hymenaea martiana (HmEtOH - 100, 200 and $\left.400 \mathrm{mg} \cdot \mathrm{kg}^{-1}\right)$, indomethacin $\left(20 \mathrm{mg} \cdot \mathrm{kg}^{-1}\right)$ and morphine $\left(10 \mathrm{mg} \cdot \mathrm{kg}^{-1}\right)$ on acetic acid induced writhing test in mice. Values are mean \pm S.E.M. ${ }^{*} \mathrm{P}<0.05,{ }^{* *} \mathrm{P}<0.01$, significantly different from control; one-way ANOVA followed by Tukey's test ( $n=6$, per group).

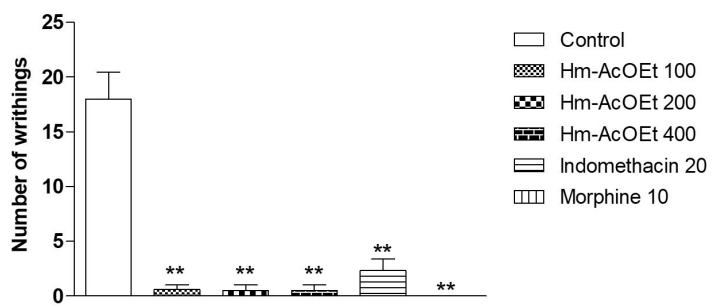

Figure 3. Effect of the ethyl acetate fraction of Hymenaea martiana (Hm-AcOEt - 100, 200 and 400 mg.kg-1), indomethacin $\left(20\right.$ mg. $\left.\mathrm{kg}^{-1}\right)$ and morphine ( $\left.10 \mathrm{mg} \cdot \mathrm{kg}^{-1}\right)$ on acetic acid-induced writhing test in mice. Values are mean \pm S.E.M. ${ }^{* *} \mathrm{P}<0.01$, significantly different from control; one-way ANOVA followed by Tukey's test ( $n=6$, per group). both (early and late phases) of the formalin test (Figure 4). $\mathrm{Hm}-\mathrm{EtOH}$ decreased by 60, 78 and 73\%, respectively, the paw licking time in the first phase, as well as 86,99 and $100 \%$, respectively, in the second phase of the formalin test. The treatment with $\mathrm{Hm}$-AcOEt at the dose of $100 \mathrm{mg} \cdot \mathrm{kg}^{-1}$ (i.p.) showed no inhibition of nociceptive response in the first phase. However, in the second phase, the group showed $96 \%$, whereas the treatment with the doses of 200 and 400 mg.kg-1 (i.p.) decreased by 51 and 59\%, respectively, the paw licking time in the first phase, as well as 97 and $100 \%$, 

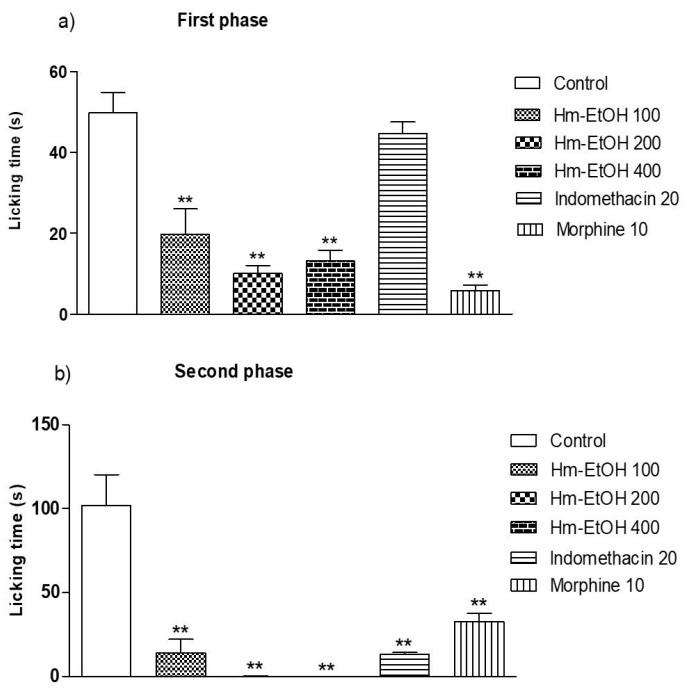

Figure 4. Effect of the ethanolic extract of Hymenaea martiana $(\mathrm{Hm}-\mathrm{EtOH}$ - 100, 200 and $\left.400 \mathrm{mg}^{\mathrm{kg}}{ }^{-1}\right)$, indomethacin $\left(20 \mathrm{mg} \cdot \mathrm{kg}^{-1}\right)$ and morphine (10 mg. $\left.\mathrm{kg}^{-1}\right)$ on formalin test in mice. Values are mean \pm S.E.M.; ${ }^{* *} \mathrm{P}<$ 0.01 , significantly different from control; ANOVA one-way followed by Tukey's test ( $n=6$, per group). (a) first phase and (b) second phase.

respectively, in the second phase (Figure 5). The reference drug indomethacin suppressed only the second phase of the formalin test, while morphine inhibited both phases of the pain stimulus $(\mathrm{P}<0.05)$.

In this test, it was found that animals treated with morphine $\left(10 \mathrm{mg} \cdot \mathrm{kg}^{-1}\right.$, i.p. $)$ showed a significantly increased stay on the hot plate at 30, 60, 90 and $120 \mathrm{~min}(\mathrm{P}<0.05)$. The animals treated with the dose of $200 \mathrm{mg} \cdot \mathrm{kg}^{-1}$ showed a significant increase at 60, 90 and $120 \mathrm{~min}$., and those treated with $400 \mathrm{mg} \cdot \mathrm{kg}^{-1}$ were significantly active at 30,60 , 90 and 120 min (Figure 6). The groups treated with $\mathrm{Hm}$ $\operatorname{AcOEt}\left(100,200\right.$ and $400 \mathrm{mg} \cdot \mathrm{kg}^{-1}$, i.p.) (Figure 7) showed a significant increase in the time on the hot plate at 30 , 60, 90 and 120 min.

The formation of edema, produced by the intraplantar administration of carrageenan, is a biphasic event, which is estimated for $1-5$ hours and was significantly reduced ( $\mathrm{P}<0.01$ ) by Hm-EtOH (200 and 400 mg.kg-1 i.p.) 1, 2, 3, 4 and $5 \mathrm{~h}$ after the administration of carrageenan, as shown in Figure 8. However, animals that received $100 \mathrm{mg} \cdot \mathrm{kg}^{-1}$ showed no significant reduction in the first and second hours. In animals that received Hm-AcOEt (100, 200 and $400 \mathrm{mg} . \mathrm{kg}^{-1}$, i.p.), the edematogenic effect induced by carrageenan was significantly reduced for $5 \mathrm{~h}$, but the reversal of edema was more pronounced in animals which received 200 and $400 \mathrm{mg} \cdot \mathrm{kg}^{-1}$. Indomethacin (20 mg.kg-1, i.p.) showed inhibition of the edema $(\mathrm{P}<0.05)$ during $5 \mathrm{~h}$ of the experiment (Figure 9).

Hm-EtOH and Hm-AcOEt (100, 200 and 400 mg.kg-1) administered $1 \mathrm{~h}$ before the injection of carrageenan inhibited the leukocyte migration $(\mathrm{P}<0.01)$ (Figure 10 and Figure 11).
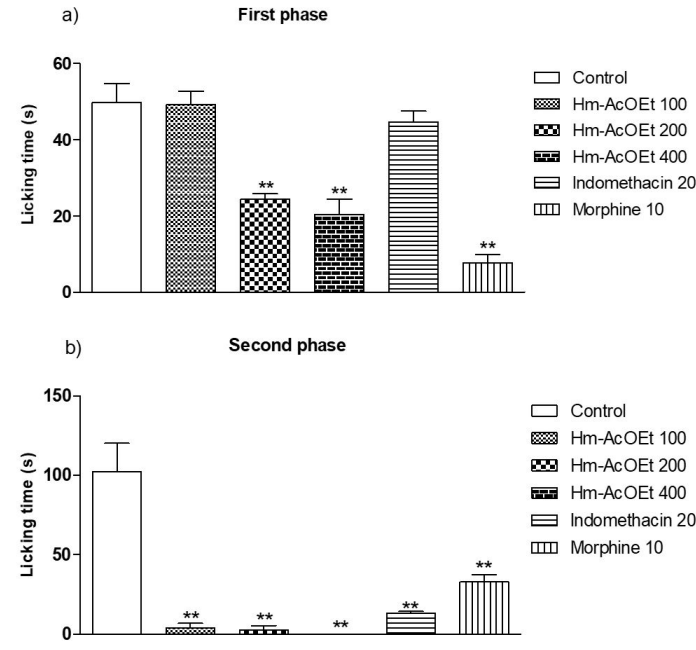

Figure 5. Effect of the ethyl acetate fraction of Hymenaea martiana (Hm-AcOEt - 100, 200 and 400 mg.kg-1), indomethacin (20 mg. $\left.\mathrm{kg}^{-1}\right)$ and morphine (10 mg. $\left.\mathrm{kg}^{-1}\right)$ on formalin test in mice. Values are mean \pm S.E.M.; ${ }^{* *} \mathrm{P}<0.01$, significantly different from control; one-way ANOVA followed by Tukey's test ( $n=6$, per group). (a) first phase and (b) second phase.

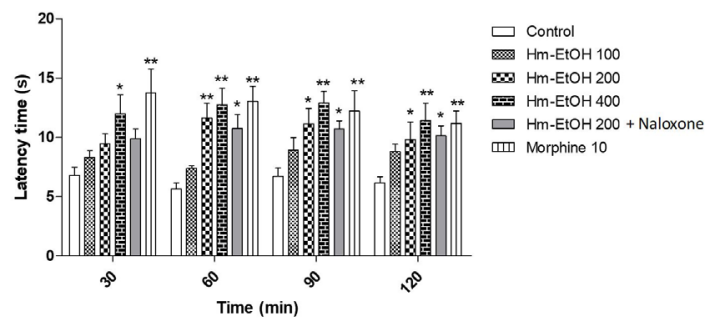

Figure 6. Effect of the ethanolic extract of Hymenaea martiana (Hm-EtOH - 100, 200 and 400 mg.kg-1), Hm-EtOH (200 mg.kg-1) + naloxone and morphine (10 mg. $\left.\mathrm{kg}^{-1}\right)$ in the hot-plate test in mice. Values are mean \pm S.E.M.; ${ }^{*} \mathrm{P}<0.05,{ }^{* *} \mathrm{P}<0.01$, significantly different from control; two-way ANOVA followed by Bonferroni's multiple comparisons test ( $n=6$, per group).

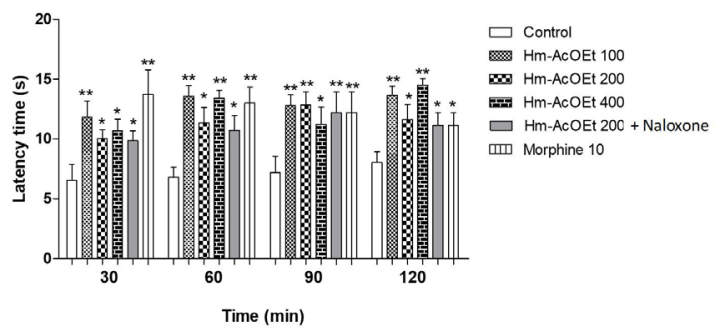

Figure 7. Effect of the ethyl acetate fraction of Hymenaea martiana (Hm-AcOEt - 100, 200 and 400 mg.kg-1), Hm-EtOH (200 mg.kg-1) + naloxone and morphine (10 mg. $\left.\mathrm{kg}^{-1}\right)$ on the hot-plate test in mice. Values are mean \pm S.E.M.; ${ }^{*} \mathrm{P}<0.05,{ }^{* *} \mathrm{P}<0.01$, significantly different from control; two-way ANOVA followed by Bonferroni's multiple comparisons test ( $n=6$, per group). 


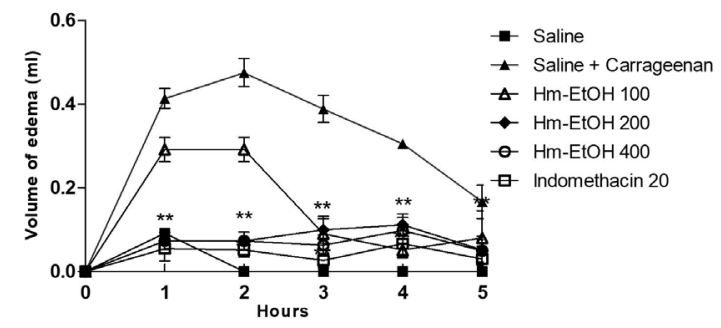

Figure 8. Effect of the ethanolic extract of Hymenaea martiana (Hm-EtOH - 100, 200 and 400 mg.kg-1) and indomethacin (20 mg. $\mathrm{kg}^{-1}$ ) on carrageenan-induced hind paw edema in mice. Values are mean \pm S.E.M. ${ }^{* *} \mathrm{P}<0.01$, significantly different from control; two-way ANOVA followed by Bonferroni's multiple comparisons test ( $n=6$, per group).

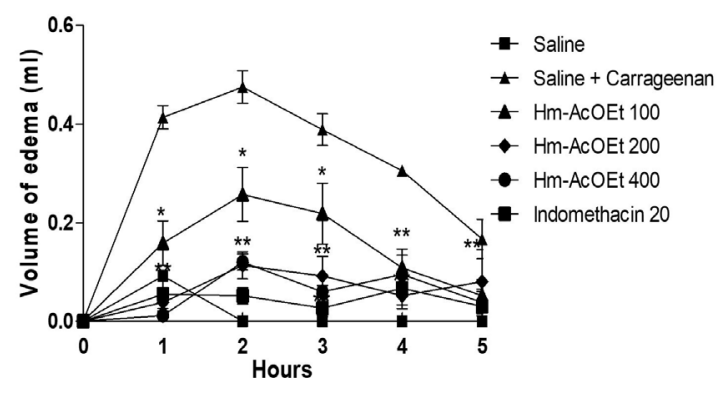

Figure 9. Effect of the ethyl acetate fraction of Hymenaea martiana (Hm-AcOEt - 100, 200 and 400 mg.kg-1) and indomethacin (20 mg. $\mathrm{kg}^{-1}$ ) on carrageenan-induced hind paw edema in mice. Values are mean \pm S.E.M.; ${ }^{*} \mathrm{P}<0.05,{ }^{* *} \mathrm{P}<0.01$, significantly different from control; two-way ANOVA followed by Bonferroni's multiple comparisons test ( $n=6$, per group).

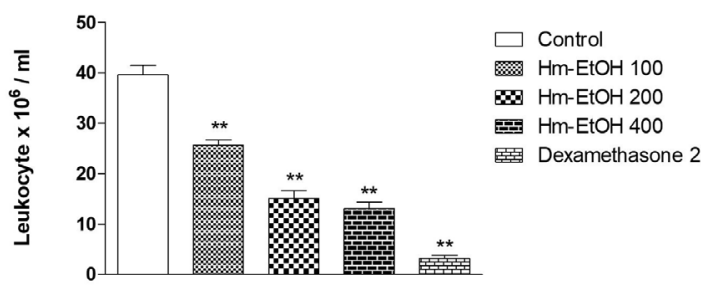

Figure 10. Effect of the ethanolic extract of Hymenaea martiana (Hm-EtOH - 100, 200 and 400 mg.kg-1) and dexamethasone (2 mg. $\mathrm{kg}^{-1}$ ) on leukocyte migration into the peritoneal cavity induced by carrageenan in mice. Values are mean \pm S.E.M.; ${ }^{* *} \mathrm{P}<0.01$, significantly different from control; ANOVA one-way followed by Tukey's test ( $n=6$, per group).

\section{Discussion}

Regarding the chemical composition of Hm-EtOH and $\mathrm{Hm}$-AcOEt, the flavonoid astilbin was unambiguously identified based on the injection of reference standard of this compound in the same chromatographic conditions. Besides, it is already known that astilbin is a chemical marker for the species Hymenaea martiana (Carneiro et al., 1993). Both the ethanolic extract and the ethyl acetate fraction of $H$. martiana contain phenolic compounds and bear antioxidant activity (Silva et al., 2012).

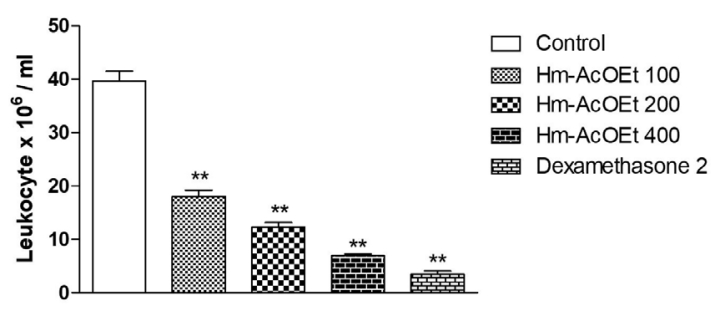

Figure 11. Effect of the ethyl acetate fraction of Hymenaea martiana (Hm-AcOEt - 100, 200 and 400 mg.kg-1) and dexamethasone (2 mg. $\mathrm{kg}^{-1}$ ) on leukocyte migration into the peritoneal cavity induced by carrageenan in mice. Values are mean \pm S.E.M.; ${ }^{* *} \mathrm{P}<0.01$, significantly different from control; one-way ANOVA followed by Tukey's test ( $n=6$, per group).

The antinociceptive effects of $\mathrm{Hm}-\mathrm{EtOH}$ and $\mathrm{Hm}$-AcOEt were evaluated using classical models of nociception induced by chemical and thermal stimuli (Le Bars et al., 2001). In addition, carrageenan-induced paw edema and the carrageenan-induced peritonitis tests also investigated the anti-inflammatory activity of these samples.

The acetic acid-induced writhing test is a non-selective test for antinociceptive studies, based on the irritation caused after the i.p. injection of acetic acid. It has been suggested that this injection can stimulate the release of a variety of endogenous mediators, particularly histamine, bradykinin, serotonin and prostaglandins (Cesário et al., 2018; Hosoi et al., 1999; Bentley et al., 1983). Thus, this model is generally associated with the release of prostanoids, resulting in increased levels of $\mathrm{PGE}_{2}$ and $\mathrm{PGF}_{2 \alpha}$ in the peritoneal fluid, and from other products of the lipoxygenase pathway, where activity of acetic acid involves the process or release of arachidonic acid metabolites (Melo et al., 2008; Duarte et al., 1988).

The formalin-induced nociception test has two distinct phases and is an evaluation method used to measure the behavioral effectiveness of antinociceptive agents (Randolph and Peters, 1997). The first phase (neurogenic phase) is caused by the direct chemical stimulation of nociceptors. Substance P, glutamate and bradykinin are thought to participate in this phase. The second phase (inflammatory phase) is related to the inflammation of the peripheral tissues (Nascimento et al., 2013), which is the result of the release of several inflammatory mediators, such as histamine, serotonin and prostaglandins (Rácz and Zimmer, 2006). The results of this test indicate the likelihood of components with anti-inflammatory capacity in the extracts, but also suggest a possible neurogenic (central) component in the analgesic profile.

Our results also showed that the extracts were effective, increasing the latency time when compared with the control group in the hot-plate test. The hotplate test on thermal stimulation is associated with central neurotransmission where the heat activates nociceptors ( $A_{\delta}$ and $C$ fibers) (Pinheiro et al., 2011). Thermal stimulus-induced hyperalgesia is specific for centrally mediated nociceptors and is thought to involve opioids (Le Bars et al., 2001; Jacob and Ramabadran, 
1978). However, the effect of Hm-EtOH and Hm-AcOEt was not reversed in the hot-plate test with use of naloxone. Thus, it was suggested that the antinociceptive effect of the extract is not mediated by the activation of opioid receptors. This effect may be related to several neurotransmitter pathways, including glutamatergic, cholinergic, serotoninergic and nitrergic systems.

The inhibition observed in the second phase of the formalin test suggested that $\mathrm{Hm}-\mathrm{EtOH}$ and $\mathrm{Hm}$-AcOEt may act as an inhibitor of prostaglandin synthesis. In order to confirm the possible anti-inflammatory activity of HmEtOH and $\mathrm{Hm}$-AcOEt, the carrageenan-induced paw edema model in mice was performed.

The edema experimental model is used for screening of substances or plant extracts with anti-inflammatory nature (Thomazzi et al., 2010). The subcutaneous administration of carrageenan in the rat paw produces an acute and progressive increase in volume in the injected paw. This edema is an essential feature of acute inflammation caused by increased vascular permeability, leading to leakage of transvascular fluid rich in proteins of high molecular weight (exudate) from the intravascular to the interstitial compartment (Aller et al., 2007). The first phase ( 1 or 1.5 hours) is predominantly characterized by the formation of an edema with action of proinflammatory mediators, such as histamine, bradykinin and serotonin on vascular permeability (Zhu et al., 2011), while the second phase (2-5 hours) is characterized by an increased formation of edema that remains for up to 5 hours (Khan et al., 2009). This phase, with a maximum peak in time of 3 hours, is normally maintained by other mediators such as cytokines (IL- $1 \beta$ and TNF- $\alpha$ ), prostaglandins and nitric oxide.

In an attempt to better characterize the antiinflammatory effect of $\mathrm{Hm}$-EtOH and $\mathrm{Hm}$-AcOEt, the test of leukocyte migration to the peritoneal cavity was made, induced by carrageenan. This phlogistic agent, when applied to the peritoneal cavity, induces an inflammatory response characterized by intense plasma exudation and migration of cells, particularly leukocytes (Zhang et al., 2011; Damas et al., 1990). This migration is the result of great stimulation of the release of inflammatory mediators such as prostaglandins, histamine, bradykinin, neuropeptides and nitric oxide (Paulino et al., 2008). These mediators are able to recruit leukocytes, such as neutrophils, in several experimental models. Substances having anti-inflammatory activity can reduce the migration of leukocytes by preventing the synthesis and/or release of chemotactic mediators or blocking some stage of the migration of leukocytes (Muller, 2002). The results obtained in this test confirm the anti-inflammatory potential of $\mathrm{Hm}$-EtOH and $\mathrm{Hm}$ AcOEt, identified in the second phase of the formalin test, which is possibly related to phenolic constituents present in both extracts, such as flavonoids identified in preliminary phytochemical screening (Silva et al., 2012). These compounds act by modulating cells involved with inflammation (inhibiting the proliferation of cells T), by inhibiting the production of pro-inflammatory cytokines (TNF- $\alpha$ and IL-1 $\beta$ ) and by modulating enzyme activity of the arachidonic acid pathway, in addition to modulating the enzyme forming nitric oxide (Coutinho et al., 2009).

\section{Conclusion}

In conclusion, this work reveals that the crude ethanolic extract and the ethyl acetate fraction from the barks of $H$. martiana have antinociceptive and anti-inflammatory effects. Results of current studies justify further studies for the isolation and identification of the causative bioactive component(s) and to elucidate the mechanism(s) lying with these effects.

\section{Acknowledgements}

This work was supported by grants from Brazilian agencies CNPq and FACEPE.

\section{References}

AGRA, M.F., FREITAS, P.F. and BARBOSA-FILHO, J.M., 2007. Synopsis of the plants known as medicinal and poisonous in Northeast of Brazil. Revista Brasileira de Farmacognosia, vol. 17, no. 1, pp. 114-140. http://dx.doi.org/10.1590/S0102-695X2007000100021.

ALLER, M.A., ARIAS, J.L., ARIAS, J.I., SANCHEZ-PATAN, F. and ARIAS, J., 2007. The inflammatory response recapitulates phylogeny through trophic mechanisms to the injured tissue. Medical Hypotheses, vol. 68, no. 1, pp. 202-209. http://dx.doi. org/10.1016/j.mehy.2006.07.004. PMid:16963191.

ALMEIDA, C.F.C.B.R., RAMOS, M.A., AMORIM, E.L.C. and ALBUQUERQUE, U.P., 2010. A comparison of knowledge about medicinal plants for three rural communities in the semi-arid region of northeast of Brazil. Journal of Ethnopharmacology, vol. 127, no. 3, pp. 674-684. http://dx.doi.org/10.1016/j. jep.2009.12.005. PMid:19969057.

ANDRADE, G.S., GUIMARÃES, A.G., SANTANA, M.T., SIQUEIRA, R.S., PASSOS, L.O., MACHADO, S.M.F., RIBEIRO, A.S., SOBRAL, M., ALMEIDA, J.R.G.S. and QUINTANS-JÚNIOR, L.J., 2012. Phytochemical screening, antinociceptive and anti-inflammatory effects of the essential oil of Myrcia pubiflora in mice. Revista Brasileira de Farmacognosia, vol. 22, no. 1, pp. 181-188. http:// dx.doi.org/10.1590/S0102-695X2011005000205.

BASTOS, L.F.S., MERLO, L.A., ROCHA, L.T.S. and COELHO, M.M., 2007. Characterization of the antinociceptive and anti-inflammatory activities of doxycycline and minocycline in different experimental models. European Journal of Pharmacology, vol. 576, no. 1-3, pp. 171-179. http://dx.doi.org/10.1016/j. ejphar.2007.07.049. PMid:17719028.

BENTLEY, G.A., NEWTON, S.H. and STARR, J., 1983. Studies on the antinociceptive action of $\alpha$-agonist drugs and their interactions with opioid mechanisms. British Journal of Pharmacology, vol. 79, no. 1, pp. 125-134. http://dx.doi.org/10.1111/j.1476-5381.1983. tb10504.x. PMid:6135474.

CARNEIRO, E., CALIXTO, J.B., MONACHE, F.D. and YUNES, R.A., 1993. Isolation, chemical identification and pharmacological evaluation of eucryphin, astilbin and engelitin obtained from the bark of Hymenaea martiana. International Journal of Pharmacognosy, vol. 31, no. 1, pp. 38-46. http://dx.doi. org/10.3109/13880209309082916.

CESÁRIO, F.R.A.S., ALBUQUERQUE, T.R., LACERDA, G.M., OLIVEIRA, M.R.C., RODRIGUES, L.B., MARTINS, A.O.B.P.B., BOLIGON, A.A., 
QUINTANS-JUNIOR, L.J., ARAÚJO, A.A.S., VALE, M.L., COUTINHO, H.D.M. and MENEZES, I.R.A., 2018. Phytochemical profile and mechanisms involved in the anti-nociception caused by the hydroethanolic extract obtained from Tocoyena formosa (Cham. \&amp; Schltdl.) K. Schum (Jenipapo-bravo) leaves in mice. Biomedicine and Pharmacotherapy, vol. 97, pp. 321-329. http://dx.doi.org/10.1016/j.biopha.2017.10.054. PMid:29091881.

COLLIER, H.O.J., DINNEEN, L.C., JOHNSON, C.A. and SCHNEIDER, C. 1968. The abdominal constriction response and its suppression by analgesic drugs in the mouse. British Journal of Pharmacology and Chemotherapy, vol. 32, no. 2, pp. 295-310. http://dx.doi. org/10.1111/j.1476-5381.1968.tb00973.x. PMid:4230818.

COUTINHO, M.A.S., MUZITANO, M.F. and COSTA, S.S., 2009. Flavonoids: potential therapeutic agents for the inflammatory process. Revista Virtual de Química, vol. 1, no. 3, pp. 241-256. http://dx.doi.org/10.5935/1984-6835.20090024.

CUNNINGHAM, A., MARTIN, S.S. and LANGENHEIM, J.H., 1974. Labd-13-en-8-ol-15-oic acid in the trunk resin of Amazonian Hymenaea courbaril. Phytochemistry, vol. 13, no. 1, pp. 294-295. http://dx.doi.org/10.1016/S0031-9422(00)91323-2.

DAMAS, J., BOURDON, V., REMACLE-VOLON, G. and ADAM, A., 1990. Kinins and peritoneal exudates induced by carrageenin and zymosan in rats. British Journal of Pharmacology, vol. 101, no. 2, pp. 418-422. http://dx.doi.org/10.1111/j.1476-5381.1990. tb12724.x. PMid:2257442.

DOMÉNECH-CARBÓ, M.T., DE LA CRUZ-CAÑIZARES, J., OSETECORTINA, L., DOMÉNECH-CARBÓ, A. and DAVID, H., 2009. Ageing behaviour and analytical characterization of the Jatobá resin collected from Hymenaea stigonocarpa Mart. International Journal of Mass Spectrometry, vol. 284, no. 1-3, pp. 81-92. http:// dx.doi.org/10.1016/j.ijms.2008.12.015.

DUARTE, I.D., NAKAMURA, M. and FERREIRA, S.H., 1988. Participation of the sympathetic system in acetic acid-induced writhing in mice. Brazilian Journal of Medical and Biological Research, vol. 21, no. 2, pp. 341-343. PMid:3203167.

DUTRA, V.F., GARCIA, F.C.P. and LIMA, H.C., 2008. Caesalpinioideae (Leguminosae) nos Campos Rupestres do Parque Estadual do Itacolomi, MG, Brasil. Acta Botanica Brasílica, vol. 22, no. 2, pp. 547-558. http://dx.doi.org/10.1590/S0102-33062008000200021.

GAZZANEO, L.R., DE LUCENA, R.F. and DE ALBUQUERQUE, U.P.. 2005. Knowledge and use of medicinal plants by local specialists in an region of Atlantic Forest in the state of Pernambuco (Northeastern Brazil). Journal of Ethnobiology and Ethnomedicine, vol. 1, no. 1, pp. 9. http://dx.doi.org/10.1186/1746-4269-1-9. PMid:16270911.

GIORDANI, R.B., PAGLIOSA, L.B., HENRIQUES, A.T., ZUANAZZI, J.A.S. and DUTILH, J.H.A., 2008. Investigação do potencial antioxidante e anticolinesterásico de Hippeastrum (Amaryllidaceae). Quimica Nova, vol. 31, no. 8, pp. 2042-2046. http://dx.doi.org/10.1590/ S0100-40422008000800024.

GIULIETTI, A.M., HARLEY, R.M., DE QUEIROZ, L.P., WANDERLEY, M.D.G.L. and VAN DEN BERG, C., 2005. Biodiversity and conservation of plants in Brazil. Conservation Biology, vol. 19, no. 3, pp. 632-639. http://dx.doi.org/10.1111/j.15231739.2005.00704.X.

HOSOI, M., OKA, T., ABE, M., HORI, T., YAMAMOTO, H., MINE, K. and KUBO, C., 1999. Prostaglandin E 2 has antinociceptive effect through EP 1 receptor in the ventromedial hypothalamus in rats. Pain, vol. 83, no. 2, pp. 221-227. http://dx.doi.org/10.1016/ S0304-3959(99)00105-0. PMid:10534593.

HUANG, G.J., PAN, C.H., LIU, F.C., WU, T.S. and WU, C.H., 2012. Anti-inflammatory effects of ethanolic extract of Antrodia salmonea in the lipopolysaccharide-stimulated RAW246.
7 macrophages and the $\lambda$-carrageenan-induced paw edema model. Food and Chemical Toxicology, vol. 50, no. 5, pp. 1485-1493. http://dx.doi.org/10.1016/j.fct.2012.01.041. PMid:22326970.

HUNSKAAR, S. and HOLE, K., 1987. The formalin test in mice: dissociation between inflammatory and non-inflammatory pain. Pain, vol. 30, no. 1, pp. 103-114. http://dx.doi.org/10.1016/03043959(87)90088-1. PMid:3614974.

JACOB, J.J.C. and RAMABADRAN, K., 1978. Enhancement of a nociceptive reaction by opioid antagonists in mice. British Journal of Pharmacology, vol. 64, no. 1, pp. 91-98. http://dx.doi.org/10.1111/j.1476-5381.1978.tb08645.x. PMid:698486.

KHAN, I., NISAR, M., EBAD, F., NADEEM, S., SAEED, M., KHAN, H., SAMIULLAH., KHUDA, F., KARIM, N. and AHMAD, Z., 2009. Anti-inflammatory activities of Sieboldogenin from Smilax china Linn.: experimental and computational studies. Journal of Ethnopharmacology, vol. 121, no. 1, pp. 175-177. http://dx.doi. org/10.1016/j.jep.2008.10.009. PMid:19007873.

KHOO, S.F., OEHLSCHLAGER, A.C. and OURISSON, G., 1973. Structure and stereochemistry of the diterpenes of Hymenaea courbaril (Caesalpinioideae) seed pod resin. Tetrahedron, vol. 29, no. 21, pp. 3379-3388. http://dx.doi.org/10.1016/S0040-4020(01)93493-3.

LE BARS, D., GOZARIU, M. and CADDEN, S.W., 2001. Animal models of nociception. Pharmacological Reviews, vol. 53, no. 4, pp. 597-652. PMid:11734620.

LEMOS, I.C.S., DELMONDES, G.A., DOS SANTOS, A.D.F., SANTOS, E.S., DE OLIVEIRA, D.R., DE FIGUEIREDO, P.R.L., ALVES, D.A., BARBOSA, R., DE MENEZES, I.R.A., COUTINHO, H.D.M., KERNTOPF, M.R. and FERNANDES, G.P., 2016. Ethnobiological survey of plants and animals used for the treatment of acute respiratory infections in children of a traditional community in the municipality of Barbalha, Ceará, Brazil. African Journal of Traditional, Complementary, and Alternative Medicines, vol. 13, no. 4, pp. 166-175. http://dx.doi.org/10.21010/ajtcam.v13i4.22. PMid:28852733.

MELO, M.G.D., ARAÚJO, A.A.S., ROCHA, C.P.L., ALMEIDA, E.M.S.A., SIQUEIRA, R.S., BONJARDIM, L.R. and QUINTANS-JUNIOR, L.J., 2008. Purification, physicochemical properties, thermal analysis and antinociceptive effect of atranorin extracted from Cladina kalbii. Biological \& Pharmaceutical Bulletin, vol. 31, no. 10, pp. 1977-1980. http://dx.doi.org/10.1248/bpb.31.1977. PMid: 18827367.

MELO, M.S., GUIMARÃES, A.G., SANTANA, M.F., SIQUEIRA, R.S., DE LIMA, A.C., DIAS, A.S., SANTOS, M.R., ONOFRE, A.S., QUINTANS, J.S., DE SOUSA, D.P., ALMEIDA, J.R., ESTEVAM, C.S., ARAUJO, B.S. and QUINTANS-JÚNIOR, L.J., 2011. Anti-inflammatory and redox-protective activities of citronellal. Biological Research, vol. 44, no. 4, pp. 363-368. http://dx.doi.org/10.4067/S071697602011000400008. PMid:22446600.

MERTENS, J., GERMER, J., SIQUEIRA FILHO, J.A. and SAUERBORN, J., 2017. Spondias tuberosa Arruda (Anacardiaceae), a threatened tree of the Brazilian Caatinga? Brazilian Journal of Biology = Revista Brasileira de Biologia, vol. 77, no. 3, pp. 542-552. http://dx.doi.org/10.1590/1519-6984.18715. PMid:27783763.

MORRIS, C.J., 2003. Carrageenan-induced paw edema in the rat and mouse. In: P.G. WINYARD and D.A. WILLOUGHBY, eds. Inflammation protocols. USA: Springer; 2003, p. 115-121. http:// dx.doi.org/10.1385/1-59259-374-7:115.

MULLER, W.A., 2002. Leukocyte-endothelial cell interactions in the inflammatory response. Laboratory Investigation, vol. 82, no. 5, pp. 521-533. http://dx.doi.org/10.1038/labinvest.3780446. PMid:12003992. 
NASCIMENTO, G.E., HAMM, L.A., BAGGIO, C.H., WERNER, M.F.P., IACOMINI, M. and CORDEIRO, L.M.C., 2013. Structure of a galactoarabinoglucuronoxylan from tamarillo (Solanum betaceum), a tropical exotic fruit, and its biological activity. Food Chemistry, vol. 141, no. 1, pp. 510-516. http://dx.doi.org/10.1016/j. foodchem.2013.03.023. PMid:23768387.

NEVES, M.C.A., NEVES, P.C.A., ZANINI, J.C., MEDEIROS, Y.S., YUNES, R.A. and CALIXTO, J.B., 1993. Analgesic and anti-inflammatory activities of the crude hydroalcoholic extract obtained from the bark of Hymenaea martiana. Phytotherapy Research, vol. 7, no. 5, pp. 356-362. http://dx.doi.org/10.1002/ptr.2650070507.

PAULINO, N., ABREU, S.R.L., UTO, Y., KOYAMA, D., NAGASAWA, H., HORI, H., DIRSCH, V.M., VOLLMAR, A.M., SCREMIN, A. and BRETZ, W.A., 2008. Anti-inflammatory effects of a bioavailable compound, Artepillin C, in Brazilian propolis. European Journal of Pharmacology, vol. 587, no. 1-3, pp. 296-301. http://dx.doi. org/10.1016/j.ejphar.2008.02.067. PMid:18474366.

PINHEIRO, B.G., SILVA, A.S., SOUZA, G.E., FIGUEIREDO, J.G., CUNHA, F.Q., LAHLOU, S., DA SILVA, J.K., MAIA, J.G. and SOUSA, P.J., 2011. Chemical composition, antinociceptive and anti-inflammatory effects in rodents of the essential oil of Peperomia serpens (Sw.) Loud. Journal of Ethnopharmacology, vol. 138, no. 2, pp. 479-486. http://dx.doi.org/10.1016/j.jep.2011.09.037. PMid:21971207.

RÁCZ, I. and ZIMMER, A., 2006. Animals models of Nociception. Stand Mouse Model Phenotyping, vol. 2006, pp. 221-235. http:// dx.doi.org/10.1002/9783527611942.ch9.

RANDOLPH, B.C. and PETERS, M.A., 1997. Analgesic effectiveness of ketorolac compared to meperidine in the rat formalin test. Anesthesia Progress, vol. 44, no. 1, pp. 11-16. PMid:9481975.

RIBEIRO, D.A., MACÊDO, D.G., OLIVEIRA, L.G.S., SARAIVA, M.E., OLIVEIRA, S.F., SOUZA, M.M.A. and MENEZES, I.R.A., 2014. Potencial terapêutico e uso de plantas medicinais em uma área de Caatinga no estado do Ceará, nordeste do Brasil. Revista
Brasileira de Plantas Medicinais, vol. 16, no. 4, pp. 912-930. http://dx.doi.org/10.1590/1983-084X/13_059.

SILVA, M.E.G.C., GUIMARÃES, A.L., OLIVEIRA, A.P., ARAÚJO, C.S., SIQUEIRA-FILHO, J.A., FONTANA, A.P., DAMASCENO, P.K.F., BRANCO, C.R.C., BRANCO, A. and ALMEIDA, J.R.G.S., 2012. HPLCDAD analysis and antioxidant activity of Hymenaea martiana Hayne (Fabaceae). Journal of Chemical and Pharmaceutical Research, vol. 4, pp. 1160-1166.

SOUZA, R.K., DA SILVA, M.A., DE MENEZES, I.R., RIBEIRO, D.A., BEZERRA, L.R. and SOUZA, M.M., 2014. Ethnopharmacology of medicinal plants of carrasco, northeastern Brazil. Journal of Ethnopharmacology, vol. 157, pp. 99-104. http://dx.doi. org/10.1016/j.jep.2014.09.001. PMid:25240589.

THOMAZZI, S.M., SILVA, C.B., SILVEIRA, D.C.R., VASCONCELLOS, C.L.C., LIRA, A.F., CAMBUI, E.V.F., ESTEVAM, C.S. and ANTONIOLLI, A.R., 2010. Antinociceptive and anti-inflammatory activities of Bowdichia virgilioides (sucupira). Journal of Ethnopharmacology, vol. 127, no. 2, pp. 451-456. http://dx.doi.org/10.1016/j. jep.2009.10.014. PMid:19837149.

TJøLSEN, A., BERGE, O.G., HUNSKAAR, S., ROSLAND, J.H. and HOLE, K., 1992. The formalin test: an evaluation of the method. Pain, vol. 51, no. 1, pp. 5-17. http://dx.doi.org/10.1016/03043959(92)90003-T. PMid:1454405.

ZHANG, C.X., DAI, Z.R. and CAI, Q.X., 2011. Anti-inflammatory and anti-nociceptive activities of Sipunculus nudus L. extract. Journal of Ethnopharmacology, vol. 137, no. 3, pp. 1177-1182. http://dx.doi.org/10.1016/j.jep.2011.07.039. PMid:21807085.

ZHU, Z.Z., MA, K.J., RAN, X., ZHANG, H., ZHENG, C.J., HAN, T., ZHANG, Q.Y. and QIN, L.P., 2011. Analgesic, anti-inflammatory and antipyretic activities of the petroleum ether fraction from the ethanol extract of Desmodium podocarpum. Journal of Ethnopharmacology, vol. 133, no. 3, pp. 1126-1131. http:// dx.doi.org/10.1016/j.jep.2010.11.042. PMid:21126565. 